\title{
Analysis of Teacher Competence ANd Teacher Performance IN THE BORDER AREA OF BENGKAYANG DISTRICT
}

\author{
Warneri \\ Universitas Tanjungpura, Pontianak, Indonesia \\ E-mail: warner.6369@yahoo.co.id
}

\begin{abstract}
This study aims to determine teacher competence and teacher performance in the learning process, and efforts made by the school so that teacher competence can be implemented optimally and know the maximum work results. The approach used in this study is qualitative. Data collection techniques used direct observation, direct communication, and communication indirectly with tools such as observation guidelines, questionnaires, and interview guidelines. Data analysis was inductive and the results of the study emphasize more meaning than generalization. Sources of the data and data in this study were teacher and headmasters as many as 40 people in the border area of Bengkayang District with Malaysia about the implementation of teacher competence and the result of teacher performance. The results showed that: (1) teacher competence in the border area of Bengkayang District, most of the teachers have implemented teacher competence well; (2) the performance of teachers in the border area of Bengkayang District, most of the teachers in implementing learning have been carried out actively and effectively and the assessment of learning also most have carried out learning evaluation to the maximum; (3) efforts made by the school to overcome teacher competence and teacher performance, in this case, are by carrying out planned and structured coaching and carried out continuously so that teachers can always carry out the mandate of the law and the awareness to improve the results that have not been maximized.
\end{abstract}

Keywords: Teacher Competence; Teacher Performance; Border Area

\section{INTRODUCTION}

Law of the Republic of Indonesia Number 14 the Year 2005 on Teachers and Lecturers explained that "The competence of teachers includes professional competence, pedagogical competence, personal competence and social competence acquired through professional education". This means that a professional teacher will always innovate, to think critically about their development, especially in improving the competence as an educator. Besides the effort to do that a teacher should think that the learning process also lacks faith and devotion as a form of improving good morality. This is similar to that reflected in our National Education System that, "Education is a conscious and planned effort to create an atmosphere of learning and learning process so that students actively develop their potential to have spiritual strength, intimacy, self-control, personality, intelligence, noble character, and the skills needed by themselves, society, nation and state " (UU, 2003).

To increase competence to be able to create an ideal teacher and always thinking to the development of learning resources can always adjust to the needs of learners and the utilization of technological development continues to grow, then as a learning resource indispensable for learners in the learning process used as an option for major progress. To create quality learning and fun things to do by a teacher one way to be creative and innovative in designing learning and doing variations in teaching to create a satisfactory performance.

When the learning process takes place, teachers have their patterns based on what pleases and that is reflected in the behavior when the learning process takes place, this is where to be seen whether the competency of a teacher is reflected as a professional teacher. Competence that is reflected from the behavior shown when learning occurs indicates that the competency standards indicate a learning process that results can be measured and the expected goals can be achieved optimally.

Yamin and Maisah (2010: 6) suggested that the competence of teachers is a qualitative description of the nature of meaningful teacher behaviors. Basically, the competency of the teacher is the ability to be able to achieve the goals set by the component knowledge, skills, attitudes, and good habits. 
Based on observations and interviews conducted to teachers in border areas such as in Sub-District of Seluas, Jagoi Babang, Sanggau Ledo, and Tujuh Belas of Bengkayang District obtained information that there are obstacles and problems relating to the implementation of the competency of teachers that will ultimately affect the performance of the teacher concerned.

Teacher performance much questioned particularly about the results obtained or the quality of the students after the completion of the learning process, the facts on the ground show that the measured values through learning evaluation unsatisfactory. Besides that the teachers so far in implementing the learning process more monotonous, that is to say from time to time implement the learning process less do the innovative, creative and less use of more advanced technology development.

The performance of a teacher is the work accomplished in performing the duties assigned to him. The existence of satisfaction and motivation in carrying out duties as a teacher also helped improve the performance achieved and the creation of learning fun. Many factors can lead to job satisfaction, such as age, years of service, remuneration derived, and the number of family responsibilities, which in turn have an impact on work performance, discipline, and quality of work.

Based on the background of the problems that have been raised, the formulation of the problem in this research is formulated as follows: (a) Does the teacher already has competence following the field? (b) How is the performance of teachers during this time after the implementation of learning? (c) Is the competency of a teacher will have an impact on the performance of teachers in implementing the learning process?

The purpose of this study was (1) to determine whether the teacher already has competence following the field, (2) to determine the performance of teachers after the implementation of learning, (3) to know the efforts made by the school that teacher competence can be implemented optimally and to know the maximum work result.

\section{LITERATURE REVIEW}

\section{A. Teacher Performance}

The performance is the result of work and progress made in the areas of their person, as well as a teachers' performance is tantamount to job performance or performance ". Teacher performance will show how well the achievements obtained by the students and the learning plan implemented.

A teacher who teaches without a good plan, then certainly the achievement of their performance is difficult to measure. Teachers will also process any difficulties that must be done in the learning that takes place during one semester.

Priatna and Sukamto (2013: 1) argued that " the teacher performance appraisal system is a rating system designed to identify the ability of teachers to perform their duties through the measurement of competence mastery shown in its performance".
Daryanto (2013: 196) argued that "teacher performance assessment is an assessment done on every item of her main task activity to develop a career, rank, and position. Implementation of the main tasks of teachers cannot be separated from the ability of teachers in the mastery and application of competence ".

Teacher performance by Trisakti (2008: 6) could be measured through: (a) expertise, knowledge, and responsibility of educators through activities of daily living, as measured by observation and portfolios, (b) the products produced by educators, such as assessment of standardized, and performance assessment learners' achievements, and products produced by educational institutions, such as standardized tests, criteria standards-based assessment, and performance assessment.

Performance is used as the basis for the evaluation and assessment or the system is an important force to influence the behavior of that work. Four factors are measured in the assessment of job performance by Gibson (Fathurrohman and Suryana, 2012: 29), namely: performance, conformance, dependability, and personal adjustment.

Sennen (2011: 73) argued that "indicators of teacher performance may include: (1) labor discipline or attendance, (2) the speed, accuracy, and quantity of work, (3) Initiatives in the works, (4) communication or cooperation, (5) results or performance, and (6) the spirit in carrying out the work". Castetter (2010: 167), "performance appraisal may be defined as a process of arriving at a judgment about an individual's past or present performance against the background of his/her environment and about his/her future potential for an organization".

Improvement in the quality of teachers in the learning process from time to time must still be done if you want the achievement of better performance. In learning a teacher seeks to continue to increase their knowledge, improve their skills, improving attitudes, and doing good habits.

Yaumi (2011: 5-6) also argued that the performance improvements include three main aspects such as (1) performance improvement for learners individually consisting of learning valuable, intelligence accommodates plural, pay attention to the destination domain of learning, oriented to learn to obtain outer and inner meaning, and can be applied both informal education settings classroom and training, (2) improved performance of teachers and instructional designers in designing and implementing effective learning and humanistic, (3) the organization's performance improvement included in disseminating the effectiveness and efficiency of learning, organizational learning, organizational performance systems view, the utilization of appropriate technology.

Yamin and Maisah (2010: 129) suggested the factors that influence performance, among others:

a. Factors personal/individual, covering elements of knowledge, skills, ability, confidence, motivation, and commitment individual owned by each teacher.

b. Leadership factors, including the quality aspects of the manager and the team leader in providing impetus, 
encouragement, guidance, and support to the work of teachers.

c. Factor team, including the quality of support and encouragement given by colleagues as a team, compactness, and the closeness of the team.

d. Factor system, including work systems, work facilities provided by the school management, process organization (school), and work culture in the organization (school).

e. Contextual factors (situational), includes the pressure and changes in the external and internal environment.

The accuracy in determining teacher learning strategies, and selecting appropriate learning models and following the material that learned will make the students motivated and able to generate enthusiasm for learning is high. Things like this can indicate that the teacher is a creative, innovative in determining learning needs.

Based on the understanding of the performance of a teacher, essential are (1) the quality of the teacher in the learning process, whether it is good and attract the attention of students, (2) the quantity, a teacher in the learning process carried out whether following the plans and targets that want to be achieved can be met or not, (3) severity of work performed, whether learning conducted following the obligations imposed or excess of which should be applied in a school, (4) atmosphere and environment work, what kind of atmosphere where the learning process, pleasant or not and what kind of also the environment around the school, support the learning process or not, and (5) a device that supports the implementation of learning, what facilities are available to support the learning process so that the learning process can take place smoothly, on time and does not cause boredom for students.

\section{B. Teacher Competence}

Mulyasa (2013: 8) argued that "efforts to increase the competence of teachers is being done lately, among others through a test of competence, performance assessment, and continuous professional development". Until now there are still many who question and doubt what is the level of professionalism of a teacher with all its competence, this is due to the benefits of the teaching profession implementation on the ground if it can be said to be a professional or not, plus the low quality of education that occurred during this time.

Daryanto (2013: 10) suggested also that because of modern society, the teacher is not yet a professional profession if only able to make the students read, write and count, or get a high score, grade, and pass the exam. Modern society considers teacher competence is incomplete if only from the expertise and skills possessed but also on the orientation of the teacher to change and innovation.

Saudagar and Idrus (2009: 64) argued that "social competence in learning activities closely related to the teacher's ability to communicate with people around the school and community where teachers live that role and how teachers communicate with the community is expected to have characteristics of its own that is a little bit much different from other people who are not teachers".

A teacher competency would indicate that the teacher in question has the ability and mastery of learning materials is broad and deep. More clearly stated by Mulyasa (2013: 42) that "professional competence is the ability of educators in the mastery of learning materials is broad and deep that enable it to guide learners gain competence specified".

Soebachman (2014: 28) argued that the teacher's role as spearhead tested, whether he can act as the inventor of the "hidden pearl" of their students or not? The students that "nyeniman" and frankly it's not wise to make skittish if overcome by the sheer reprimanded or may not take the exam semester. For a "stubbornness" that other general nature of the kind of punishment might be effective, but for obstinacy "nyeniman" such as the case above, it is not going to be effective. In this case, the creativity and capabilities of the teacher are staked to seek a solution to be exact.

In this study, researchers put more pressure approach is theoretically following the Law on Teachers and Lecturers of the Republic of Indonesia Number 14 of 2005 on the four competencies that must be owned by an education personnel and teachers' performance in carrying out its duties proposed by Wahab and Umiarso (2011: 123) that the factors that affect the performance of teachers, namely:

1. Personality and Dedication

Personality or attitude that is shown in the everyday teacher concerned, meaning the whole attitude and actions of the teacher is a picture of the personality of the teacher.

2. Professional development

Teacher professional development emphasis on mastering science or management capabilities along with strategy implementation.

3. Ability to teach

The teaching capabilities of the teacher is a reflection of teachers' mastery of his competence. This will look like what knowledge and skills a teacher in the learning process.

\section{METHODOLOGY}

\section{A. Stages Research}

This research was qualitative. Research carried out by the stages: (a) make a research proposal, (b) conduct field surveys, (c) undertake research/data collection, (d) processing of research data, (e) preparation of a progress report on the study, f) preparation of research reports, g) research seminar.

\section{B. Research Variable}

The variables in this study consisted of two variables: the competence of teachers following the Law on Teachers and Lecturers No. 14 of 2005 which consists of professional competence, pedagogical competence, personality competence, and social competence and variable of teacher performance with indicators of personality and dedication, professional development and the ability to teach. 


\section{Model Used}

This study used a model of descriptive qualitative approach with the design of ex post facto to study the facts that have occurred and experienced by respondents. This study did not conduct the treatment to research subjects and just dig the data that the event has occurred by using a questionnaire.

\section{Research Design}

The study design was carried out based on the variables that had been identified and defined in a study. The design of this research was a case study design, meaning that research had focused on a phenomenon are chosen and to be understood in-depth, by ignoring other phenomena.

\section{E. Data Collection Technique}

Data collection techniques used: (a) direct communication, (b) indirect communication, and (c) direct observation. While the instruments used are (a) guidelines for interviews, (b) questionnaire, (c) guidelines for observation.

\section{F. Data Analysis}

Data analysis was a method used to process research data, including:

1. Domain analysis

Sugiyono (2014: 103) stated that "domain analysis is generally performed to obtain a general overview of the social situation under study or research object".

2. Taxonomic analysis

Sugiyono (2014: 110) stated that "taxonomic analysis is an analysis of the overall data collected by the domain that has been set".

3. Domain percentage of interviews result

Domain percentage of interviews result was done with the Equation (1).

Domain Percentage $=\frac{\text { Number of respondents responses per domain }}{\text { Total responses of respondents per indicator }} \times 100 \%$

4. Indicators percentage of interviews result

Indicators percentage of interviews result conducted with the Equation (2).

Domain Percentage $=\frac{\text { Number domain }}{\text { Total domain }} \times 100 \%$

\section{IV.RESULTS AND DISCUSSION}

\section{A. Teacher Competence}

\section{Professional Competence}

Instruments of professional competence in the research, there are five items consisting statement: (1) teachers are always learning to master the subject matter expertise, (2) teachers are capable and always learn to use the tool as supporting media in learning and make it your own, (3) Teachers always try and can find their learning resources without waiting for them to be provided from school, (4) teachers are always learning and able to master how to apply information technology to improve the effectiveness of student's learning, (5) the teacher always keep learning and trying to be able to follow a training or seminar for the advancement of learning in school.

Mastery of the subject matter obtained most of the teachers strongly agreed that they have always wanted to learn about the subject matter they teach to keep in control areas of expertise. Use of the tool as the media in the learning process most teachers could not agree on its ability to always want to learn to use the tool as a medium of learning or want to make it yourself.

Learning resources acquired the vast majority of teachers strongly agree about the efforts of teachers and their ability to seek their sources of learning without waiting to be provided by the school. Willingness to learn and the ability of teachers to master and apply information technology to improve the effectiveness of student learning. Most teachers agree about his ability to always want to learn about the procurement of information technology by making it yourself. The desire to learn as training or seminar for the advancement of the learning process. Most of the teachers strongly agree about the desire to learn and follow the training process or seminar.

\section{Pedagogical Competence}

The pedagogical instrument in this research there are six items or statements which comprises: 1) The teacher continues to be able to understand well the characteristics of their students, (2) The teacher can understand the potentials that exist on students, (3) Teachers always notice and pay attention to the potential of the student and guide students so students become achievers, (4) the teacher always use the Indonesian language in every association in the school and the classroom, (5) teachers can assess students' progress, (6) teachers often do an evaluation to determine the value of students and establish good communication with parents. Teacher's efforts to be able to understand the characteristics of students largely agree to try to be able to understand well the characteristics of their students.

Efforts to understand the potential that exists in students most of the students agreed that they will strive to be able to understand the potential that exists in students. The teacher's effort to always see and pay attention to students' potential to train and guide them so that students become achievers mostly agrees that they will always strive to be able to guide and train students who have the potential to be more achievers.

The use of Indonesian in every association largely agree. Assessment of student learning progress well obtained as much as $50 \%$ strongly agree and $50 \%$ agree to the teachers in the border area to assess students' learning progress well. Evaluation to determine the value of students and establish good communication with the parents mostly agreed to determine the value of students and establish good communication with parents. 


\section{Social Competence}

Social competence in the study visits of five aspects as follows: (1) as an educator is always willing to learn and create a good learning environment, so the learning process runs smoothly, (2) as an educator can communicate and interact, both with fellow teachers, the principal, with the parents and the students themselves, (3) as an educator can always instill a positive attitude and behave well and decently following the values and norms that apply, (4) as an educator always implement school culture adapted to the applicable rules, (5) as an educator able to understand and master the technology that continues to develop for the sake of learning.

Learning and create a good learning environment so that the learning process runs smoothly most of the teachers agree. An understanding of the communication fabric between the parties concerned in the learning process as the school and the parents, the teachers must be maintained for smooth learning, so that if there are obstacles or problems with good interaction the problems that arise, such as the relationship between school and parents and community leaders who influence the children's education process strongly agree. Values and norms that apply and are held in high esteem by the community, most teachers strongly agree that the teachers are very understanding about understanding the values and norms that apply.

Application of culture in schools that are tailored to the norms and upheld by the society that the vast majority of teachers strongly agree to always strive to implement school culture in line with the norms. The ability to master and understand the changes due to the impact of globalization is happening today is the result that the majority agrees to be able to master and understand the impact of globalization which occur in everyday life.

\section{Personality Competence}

Implementation of the learning process with glad and sincere hearts as a profession largely agree that the teachers implementing the learning process constituted with glad and sincere hearts. The feeling of having affection towards students without discrimination most said that they agreed that the teachers in carrying out their profession had compassion and did not discriminate in their treatment of students. The treatment of saying languages that can offend students' hearts and feelings mostly suggests that the teacher in carrying out his task never issued a language that can offend students.

\section{B. Teacher Performance}

The level of teacher performance can be known through performance evaluations carried out periodically and systematically regarding the implementation of the work of a teacher including in his future development efforts.

According to Gibson (Fathuroohman and Suryana, 2012: 29), four factors are measured in judging work performance: (1) Performance, involves the ability for promotion of employees, achievements in completing the work; (2) Conformance, reflect how individuals cooperate with superiors and colleagues as well as regulatory compliance organization; (3) Dependability, see how far the level of discipline of employees against the rules set and approved by the employees themselves; (4) Personal Adjustment, see how the employees of the emotional side to adapt to the work environment.

It is intended that the employee, in this case, is the profession of a teacher in carrying out his professional duties. Besides must do the planning, implementation, and evaluation of the learning process. Lesson plans which include the formulation of what will be a goal of the lesson plan following the characteristics of students to 40 teachers gained strongly agree that most teachers in planning always pay attention to the objectives to be achieved.

Learning planning includes the readiness of learning materials and what will be conveyed to students with the concept of strategies, models, and media that will be used. A learning plan that includes planning for effective learning activities, in general, agrees that the teacher in planning learning activities always planned effectively. Learning planning which includes the selection of learning resources or learning media that is following most teachers agrees the teachers can determine the appropriate learning resources and or available learning media following the material and learning strategies used.

\section{Active and Effective Teachers}

Implementation of active and effective learning activities that include start learning effectively following the plans made, the majority of teachers agree that teachers always start with effective learning activities following the plans made.

In the process of learning undertaken by a teacher who is active and effective which includes mastery of the material or subject matter content to be the area of expertise of teachers, Most teachers strongly agree that teachers can master the subject matter that is their area of expertise.

To do that learning can be fun includes the application of the learning strategies appropriate to the objectives to be achieved, the majority of teachers agree teachers can implement effective learning strategies and following the objectives to be achieved.

A learning activity that can foster students' motivation and interest is high in these activities include utilizing a source of learning or learning media in the learning process most teachers agree teachers can utilize learning resources or learning media in the learning process.

Therefore, teachers should be able to understand what he had done when the learning process that looks fun or not and how motivating and maintaining student engagement during the learning process, most of the teachers strongly agreed that teachers can do motivation and maintaining student involvement in the learning process.

Display a teacher in the learning process should be interesting and authoritative and the language used by the teacher must show how to use the Indonesian language is good and true, so that students easily understand and comprehend the material presented. 
The learning process is carried out following the stages of implementation compiled in the learning implementation plan including the preliminary process, the core process, and in ending the learning effectively and most teachers agree that the teachers can carry out the process of ending or closing the learning according to the plan made.

\section{Learning Assessment}

Learning assessment in the design of evaluation tools to measure student learning progress and success, most teachers agree that in the learning assessment they can design and determine an appropriate evaluation to get student learning outcomes.

Learning assessment includes an assessment of cognitive, affective, and psychomotor and is based on the design of the lesson plan that had been developed as a learning program semester.

Assessment of learning that includes all components of the assessment carried out to determine the outcomes of student learning outcomes after a series of learning activities must be following the draft assessment that has been planned in the lesson plan.

\section{CONCLUSIONS}

\section{A. Conclusions}

1. The competence of teachers in the border area of Bengkayang District with Malaysia largely been good, only a small portion that is still lacking. Teachers have been carrying out duties following the competence of teachers as mandated in the Law of the Republic of Indonesia on teachers and lecturers.

2. The performance of teachers in the border area of Bengkayang District with Malaysia largely been good, only a few teachers have poor performance. Teachers in the implementation of learning have done actively and effectively and in the assessment of learning must have been carried out to the maximum.

3. Efforts made by the school to overcome teacher competence and teacher performance, in this case, are by conducting planned and structured coaching and carried out continuously so that teachers can always carry out the mandate of the law and there is awareness to improve the results that have not been maximized.

B. Suggestions

Based on the conclusions put forward, then put forward suggestions include:

1. A teacher can always improve their competence through the deepening and development of science, improvement of teaching skills through creative and innovative the better to improve performance.

2. Teachers are expected to always develop the ability in the implementation of learning, to create an interesting variation, which further facilitates innovation in teaching and creative in creating a model of learning by utilizing the available media.
3. Teachers are expected to continuously learn and follow the rapid technological developments in digital industrial era 4.0 that teachers are not left behind information, especially those related to knowledge following their competence and the use of the equipment and learning media that continues to grow.

\section{REFERENCES}

B.Uno, Hamzah. (2011). Profesi Kependidikan, Problema, Solusi, dan Reformasi Pendidikan di Indonesia. Jakarta : Bumi Aksara.

Daryanto. (2013). Standar Kompetensi dan Penilaian Kinerja Guru Profesional. Yogyakarta: Gava Media.

Djamarah, Syaiful Bahri. (2012). Prestasi Belajar dan Kompetensi Guru. Surabaya: Usaha Nasional.

Fathurrohman, Pupuh and Aa. Suryana. (2012). Guru Profesional. Bandung: Refika Aditama.

Karwati, Euis and Donni, Juni Priansa. (2013). Kinerja dan Profesionalisme Kepala Sekolah, Membangun Sekolah Yang Bermutu. Bandung: Alfabeta.

Kunandar. (2011). GuruProfesional, Implementasi Kurikulum Tingkat Satuan Pendidikan (KTSP) dan Sukses dalam Sertifikasi Guru. Edisi Revisi, Jakarta: Rajawali Press.

Lubis, Grafura dan Ari, Wjayanti. (2012). Metode dan Strategi Pembelajaran Yang Unik. Jakarta: Bumi Aksara.

Martinis, Yamin and Maisah. (2010). Standarisasi Kinerja Guru. Jakarta: Gaung Remaja Persada.

Moore, D. Kennetf. (2005). Effective Instructional Strategies, from Theory to Practice. New Delhi: Sage Publications.

Nawawi, Hadari. (2012). Metode Penelitian Bidang Sosial, Yogyakarta: Gajah mada University Press.

Priatna, Nanang and Tito Sukamto. (2013). Pengembangan Profesi Guru. Bandung: Remaja Rosdakarya.

Reigeluth, Charles. (2003). Instructional-Design Theorities and Models: An Overview of Their Current Status. New Jersey: Lowrence Eribaum Associte.

Saondi, Ondi and Aris Suherman. (2010). Etika Profesi Keguruan. Bandung: Refika Aditama.

Saudagar, Fachruddin and Ali Idrus. (2009). Pengembangan Profesionalisme Guru. Jakarta: GP-Press dan FKIP Universitas Jambi.

Sennen, Eliterius. (2011). Hubungan Kualifikasi Akademik Guru, Kompetensi, Motivasi Kerja Guru dengan Kinerja Guru Sekolah Dasar Kecamatan Langke Kabupaten Manggarai. Tesis. Yogyakarta: UNY.

Shoimin, Aris. (2013). Excellent Teacher, Meningkatkan Profesionalisme Guru Pasca/Sertifikasi. Semarang: Dahara Price.

Soebachman, Agustina. (2014). Saatnya Guru Menjdi Guru Terhebat. Yogyakarta:IN AzNa Books.

Sugiyono. (2014). Statistika Untuk Penelitian. Bandung: Alfabeta.

(2012). Metode Penelitian Kombinasi (Mixed Methods). Bandung: Alfabeta. 
Syaefudin, Udin Saud. (2012). Pengembangan Profesi Guru. Bandung: Alfabeta.

Trisakti, Y. (2008). Kualitas Kinerja Widyaiswara Berdasarkan Penilaian Peserta Pendidikan dan Pelatihan di Lembaga Penjaminan Mutu Pendidikan. Disertasi. Jakarta: UNJ.

Undang-Undang Republik Indonesia Nomor 14 Tahun 2005 tentang Guru dan Dosen.
UU. (2003). Undang-Undang No. 20 Tahun 2003 tentang Sistem Pendidikan Nasional. Bandung: Citra Umbara.

Yaumi, Muhammad. (2011). Peningkatan Kinerja Guru Melalui Aktivitas Pembelajaran Berbasis Kecerdasan Jamak. Disertasi. Jakarta: Program Pascasarjana Universitas Negeri Jakarta. 